\title{
REDACTIONEEL
}

\section{Experimenten in de criminologie}

\author{
Christianne de Poot, Jan-Willem van Prooijen \& Jan de Keijser
}

In het voorjaar van 2007 publiceerde het Tijdschrift voor Criminologie een themanummer getiteld 'Experimentele criminologie en criminologische experimenten', dat gewijd was aan het gebruik van experimentele designs in criminologisch onderzoek. De daarin beschreven experimenten hadden vooral betrekking op de effectiviteit van preventiemaatregelen en strafrechtelijke interventies. In de bijdragen aan dat themanummer werd ingegaan op de dilemma's die zich bij dit soort onderzoek voordoen.

$\mathrm{Nu}$, tien jaar later, is het tijd om de balans op te maken. Heeft de experimentele onderzoeksmethode inmiddels een weg gevonden naar andere criminologische onderzoeksdomeinen? Welke criminologische onderzoeksvragen lijken zich goed te lenen voor experimenteel onderzoek? En tot welke inzichten heeft de introductie van experimenten in de criminologie geleid?

Om antwoord te vinden op deze vragen hebben we een nieuw themanummer samengesteld over criminologische experimenten. De call for papers leverde een verrassend divers palet op van experimenteel criminologisch onderzoek dat op dit moment in Nederland wordt verricht. Om recht te doen aan de variëteit in onderzoeksvragen, gebruikte methoden en oplossingen die onderzoekers kiezen voor de dilemma's waarvoor ze zich bij het uitvoeren van criminologische experimenten gesteld zien, hebben we een dubbelnummer samengesteld over dit thema.

De experimentele benadering is in de sociale wetenschappen van oudsher het domein van de psychologie en werd in de criminologie lange tijd van de hand gewezen. Experimenten zouden een te simplistische weergave van de werkelijkheid vormen, waardoor er te weinig oog zou zijn voor de ingewikkelde sociale processen en contexten die zich in de weerbarstige werkelijkheid voordoen (Pawson \& Tilley, 1998). Ook zou er te weinig oog zijn voor individuele verschillen die juist in de criminologie zo belangrijk zijn, voor de moeilijk benaderbare populatie waarop criminologisch onderzoek zich richt, en voor het feit dat het uit ethisch oogpunt lang niet altijd mogelijk is om de sociale werkelijkheid waarin criminologen geïnteresseerd zijn te manipuleren (Bijleveld, 2003; Van der Laan e.a., 2007). Deze dilemma's, die tien jaar geleden in het introductieartikel van het themanummer over experimentele criminologie werden besproken (Van der Laan e.a., 2007), zijn onverminderd actueel; ze zijn immers eigen aan de benadering en de criminologische onderzoeksvragen zijn niet wezenlijk veranderd. Inmiddels heeft het experimentele onderzoek toch terrein gewonnen en zien steeds meer onderzoekers in dat experimenten naast nadelen ook belangrijke voordelen bieden. Zo kan met experimenteel onderzoek, meer dan met welke andere onderzoeksmethode dan ook, uitstekend de causale en unieke invloed van een theoretisch 
belangrijke variabele worden onderzocht. Experimenteel onderzoek levert dus niet alleen maar boeiende discussiepunten op over de grenzen van wat experimenteel zou kunnen of moeten worden onderzocht. Het levert ook innovatieve onderzoeksmethoden en analysetechnieken op die navolging verdienen, en nieuwe inzichten waar de wetenschap en de praktijk mee zijn gebaat. Dat het altijd beter kan, en dat er altijd nader onderzoek gewenst is, wordt door de auteurs van dit nummer expliciet onderkend, maar dat geldt evengoed voor onderzoek dat gebruik maakt van niet-experimentele methoden.

Wat maakt een experiment nu zo interessant en nastrevenswaardig? De keuze voor een experimentele benadering wordt primair ingegeven door de wens om causale hypothesen te toetsen. In een experiment kan het effect van bepaalde factoren op een uitkomstmaat, door de experimentele manipulatie daarvan en de randomisering van proefpersonen over de verschillende condities, heel precies onderzocht worden. Deze nauwkeurigheid wordt geboden doordat de manipulatie van de onafhankelijke variabele plaatsvindt in een geheel of grotendeels gecontroleerde omgeving. Daardoor kan via experimenteel onderzoek vastgesteld worden wat de unieke effecten zijn van een onafhankelijke variabele. Dit in tegenstelling tot veel niet-experimentele methoden, waarin vaak niet uit te sluiten is dat de effecten van de onafhankelijke variabelen toe te schrijven zijn aan andere, nietgemeten factoren. Hoe goed het lukt om de causale effecten van de gemanipuleerde variabele in beeld te krijgen, wordt grofweg bepaald door een drietal factoren:

- de interne validiteit van het experiment, waarmee wordt gedoeld op de mate waarin gevonden verschillen tussen de groepen op de gemeten variabele toegeschreven kunnen worden aan de experimentele manipulatie of interventie, en niet aan een andere invloed of eigenschap waaraan de onderzoeksgroepen in verschillende mate blootstonden;

- de externe validiteit van het experiment, die bepaald wordt door de mate waarin de resultaten uit het onderzoek gegeneraliseerd kunnen worden naar andere personen, situaties, omstandigheden, metingen, tijdstippen en dergelijke dan degenen die deel uitmaakten van de gekozen onderzoeksopzet. De externe validiteit bepaalt dus of de resultaten alleen zichtbaar zullen zijn binnen de gekozen experimentele setting, of dat het robuuste bevindingen zijn die ook onder andere omstandigheden optreden. Een specifieke vorm van externe validiteit betreft de ecologische validiteit, een aanduiding voor de mate waarin de resultaten geldig zijn in de dagelijkse praktijk. Robuuste bevindingen die in een laboratorium onder allerlei omstandigheden kunnen worden gevonden, blijken in de praktijk soms overschaduwd te worden door sterke factoren die in de dagelijkse praktijk een rol spelen, maar die in het experiment buiten spel waren gezet;

- de mate waarin het experiment meet wat het beoogt te meten. Deze factor hangt af van een groot aantal andere aspecten, zoals de constructvaliditeit, die gaat over de mate waarin de factor die verondersteld wordt in de praktijk te werken inderdaad met de uitgevoerde manipulatie kan worden gemeten; de populatievaliditeit, die betrekking heeft op de mate waarin de steekproef een 
afspiegeling is van de doelpopulatie en daarmee nauw samenhangt met externe validiteit; de statistische conclusievaliditeit, die bepaalt of de te onderzoeken verbanden kunnen worden gedetecteerd en in hoeverre daar waarde aan mag worden gehecht, bijvoorbeeld gezien de grootte van de steekproef, de veronderstelde effectgrootte en de gebruikte statistische toetsen; en de predictieve validiteit, die bepaalt in hoeverre de uitkomsten van een bepaalde test toekomstig gedrag kunnen voorspellen.

In dit dubbelnummer over experimenten in de criminologie zijn negen bijdragen opgenomen die een groot spectrum bestrijken aan onderwerpen en methoden, en die ook op de genoemde validiteitsmaten soms grote verschillen laten zien. De onderzoeken lopen uiteen van een natuurlijk experiment naar de effecten van de invoering van 'de wietpas' op onder andere het aantal bezoekers, de ervaren overlast en het drugstoerisme rond coffeeshops tot een experiment onder criminologen naar de invloed van hun walgingsgevoeligheid op de strategie waarmee zij naar beeldmateriaal van een bloederige plaats delict kijken, en naar de mate waarin dit hun oordeel over de ernst van de zaak en de hoogte van de strafmaat beïnvloedt. In alle bijdragen hebben de auteurs hun methodologische keuzen geëxpliciteerd, en gaan ze in op het gevolg van de gemaakte keuzen voor de interpretatie van de resultaten.

Vijf bijdragen gaan over de effecten van maatregelen, interventies of de bejegeningen door professionals, twee over oordelen en beslissingen ten aanzien van exdelinquenten als werknemer of als samenwoonpartner, en twee over de wijze waarop percepties en beslissingen van professionals in de strafrechtsketen door de presentatie van informatie worden beïnvloed. We laten deze negen bijdragen hier kort de revue passeren om daarmee het brede palet te illustreren van onderwerpen en methoden die in dit nummer bijeen zijn gebracht.

Het artikel van Van Ooyen-Houben, Korf, Bieleman en De Witte beschrijft een natuurlijk experiment naar de effecten van de invoering van de wietpas. Doordat de wietpas gefaseerd werd ingevoerd, was het mogelijk om de effecten van deze interventie quasi-experimenteel te onderzoeken door voor- en nametingen te verrichten bij een experimentele groep van zeven gemeenten die de wietpas invoerden, en een vergelijkingsgroep van zeven gemeenten waarin dit niet gebeurde. Doel van dit 'natuurlijk experiment' was om te meten hoe de overlast rond coffeeshops, het drugstoerisme, het aantal coffeeshopbezoekers en de omvang van de illegale gebruikersmarkt door de invoering van de wietpas werden beïnvloed. Hoewel het onderzoek minder mooi verliep dan oorspronkelijk was voorzien, onder andere door initiële verschillen tussen de groepen en door verschillen in de wijze waarop de implementatie verliep, is het volgens de onderzoekers toch mogelijk om op grond van alle onderzoeksbevindingen tezamen causale conclusies te trekken over de effecten van het nieuwe beleid. Door de invoering van de wietpas raakten de coffeeshops niet alleen een flink deel van hun niet-ingezeten klanten, maar ook een groot deel van hun ingezeten klanten kwijt. Tegelijk was er een groei te zien van de illegale gebruikersmarkt. Hoewel het drugstoerisme en de 
overlast van de coffeeshops afnamen, was er een toename van de overlast door dealactiviteiten op straat.

De bijdrage van Wermink, Ramakers, Nieuwbeerta, De Keijser en Dirkzwager gaat over een quasi-experiment naar de effecten van detentietermijn op recidivekans. In dit onderzoek werden longitudinale gegevens gebruikt van een grote groep ex-gedetineerden. Door middel van de statistische techniek van propensity score matching werden verdachten geselecteerd die vergelijkbaar waren op allerlei voor de onderzoeksvraag relevante kenmerken waarover cijfers voorhanden waren, maar die van elkaar verschilden wat betreft de duur van hun detentie. Voorts werden voor die verschillende groepen de recidivekansen berekend in de eerste zes maanden na de vrijlating. Het onderzoek laat zien dat de detentieduur geen invloed heeft op de recidivekansen.

Propensity score matching of andere vormen van post-hoc-matching maken het in beginsel mogelijk om niet-experimenteel verzamelde gegevens toch als zodanig te herschikken en te analyseren. Een dergelijke statistische ingreep kent natuurlijk zijn eigen problemen. Het artikel van Elffers gaat over de kanttekeningen van quasi-experimentele effectstudies, waarin gebruik wordt gemaakt van matching. In deze methodologische bijdrage betoogt de auteur dat de resultaten van quasiexperimenten veel beter op waarde kunnen worden geschat als rekening wordt gehouden met de aard en omvang van de oorspronkelijk verzamelde gegevens die in de matchingsprocedure niet zijn geselecteerd voor de verdere analyses. Elffers presenteert een methode waarmee de matchingsprocedure en de waarde van resultaten van quasi-experimenten met post-hoc-matching transparanter kunnen worden gemaakt en beter kunnen worden beoordeeld.

Sprado, Fischer en Van Reemst onderzochten of de informatievoorziening van UWV-medewerkers aan hun klanten het agressieniveau van die klanten kon beïnvloeden. Dit deden ze aan de hand van een scenario-experiment onder ruim 1.400 UWV-klanten. Doordat er werd gewerkt met scenario's was de interne validiteit relatief hoog. Scenario's bieden immers meer experimentele controle dan quasiexperimentele studies, en proefpersonen kunnen random aan condities worden toegewezen. Dit ging wel ten koste van de externe validiteit, die in dit onderzoek relatief laag was. Het is nu eenmaal niet eenvoudig om echte agressie te meten met behulp van een scenariostudie. Desalniettemin laat dit onderzoek interessante effecten zien. De auteurs concluderen op grond van hun bevindingen dat een adequate informatievoorziening het agressieniveau van klanten in de richting van de medewerkers kan beïnvloeden.

Ook Koster, Bal, Van der Leun en Kunst deden onderzoek naar de effecten van de wijze waarop mensen door professionals worden bejegend. In dit geval ging het om het effect van politierespons op de medewerkingsbereidheid van slachtoffers. Dit onderzoek werd verricht aan de hand van een vignettenstudie met studenten. Ook hier was er betrekkelijk veel controle over de onafhankelijke variabele, maar daardoor tegelijkertijd een verlaagde externe validiteit, omdat er gebruik werd gemaakt van vignetten en van een specifieke groep respondenten. Ook dit onderzoek laat interessante verbanden zien. Zo lijkt een negatieve politierespons de 
bereidheid om medewerking te verlenen aan de politie te verminderen. Dit effect lijkt voor een deel toegeschreven te kunnen worden aan een verminderd vertrouwen in de politie. Of een rechtvaardige bejegening de medewerkingsbereidheid van slachtoffers kan vergroten, zal onderzoek in de praktijk moeten uitwijzen.

Twee bijdragen gaan over de vraag of, en zo ja op welke wijze, het oordeel van mensen over de geschiktheid van een persoon als werknemer of als samenwoonpartner wordt beïnvloed door diens eerdere strafrechtelijke veroordeling.

Het artikel van Van den Berg, Blommaert, Bijleveld en Ruiter beschrijft een onderzoek naar de arbeidsmarktkansen van mensen met een strafrechtelijke veroordeling. Dit werd experimenteel getoetst door identieke sollicitatiebrieven met identieke cv's te verzenden in reactie op internetvacatures, maar door in deze brieven een eerdere strafrechtelijke veroordeling en de etniciteit van de sollicitant te variëren. Verrassend genoeg laten de resultaten zien dat sollicitanten met een niet-westerse naam significant minder vaak worden geselecteerd dan westerse sollicitanten, en dat de eerdere veroordeling er nauwelijks toe doet.

Het onderzoek van Beijers, Van Prooijen en Bijleveld gaat over de veronderstelde 'onaantrekkelijkheid' van mensen met een eerder politiecontact als samenwoonpartner. Onderzocht werd of de recentheid van het delict, het hebben van een baan en het hebben van een strafblad hierop van invloed waren. Dit werd onderzocht met behulp van een vignettenstudie. Aan de hand van een fictieve casus werd studenten gevraagd of zij iemand zouden adviseren om samen te gaan wonen met een partner die in het verleden een delict had gepleegd. De interne validiteit is relatief hoog door de grote controle over de informatie die respondenten te zien krijgen, maar de externe validiteit is in dit experiment nogal beperkt omdat de afhankelijke variabele een advies van een student is aan iemand die in een fictieve casus voor de keuze staat waar de onderzoeksvraag feitelijk betrekking op heeft. De resultaten van dit onderzoek laten zien dat studenten een positiever samenwoonadvies geven als de delinquent een baan heeft en als het delict langer geleden is gepleegd.

Tot slot zijn er twee bijdragen over de invloed van de wijze en het moment waarop informatie in een strafrechtelijk onderzoek wordt gepresenteerd op percepties en beslissingen van professionals in de strafrechtsketen. De eerste groep professionals betreft forensische rechercheurs, de tweede groep betreft leden van de rechterlijke macht.

In het onderzoek van Meeuwissen, De Gruijter en De Poot naar scenariovorming en de interpretatie van sporen door forensische rechercheurs staat de introductie van mobiele forensische identificatietechnieken centraal, die het mogelijk maken al op de plaats delict analyseresultaten van DNA- en vingersporen te ontvangen. Het is de vraag hoe die snelle analyseresultaten de interpretatie van de plaats delict en het oordeel over de waarde van de sporen beïnvloeden. Dit werd onderzocht door forensische rechercheurs een gesimuleerd plaats delict onderzoek uit te laten voeren waarbij de analyseresultaten en het moment waarop de analyseresultaten werden verstrekt, werden gemanipuleerd. Snelle analyseresultaten blijken de scenariovorming van forensische rechercheurs te beïnvloeden, en 
deze invloed blijkt afhankelijk van het moment waarop deze informatie wordt verstrekt. Kennis hierover kan gebruikt worden bij de implementatie van deze technieken in de opsporingspraktijk.

Het onderzoek van Van Dillen en Vanderveen heeft als doel na te gaan of beeldmateriaal dat dankzij de digitalisering van processtukken steeds vaker wordt bekeken, getoond en bediscussieerd in de rechtszaal, van invloed is op het oordeel dat mensen zich vormen over delicten. Verondersteld wordt dat beeldmateriaal emoties kan opwekken die van invloed zijn op de informatieverwerking, en daarmee op de gepercipieerde ernst van het delict en de mate van schuld. Om dit te onderzoeken werden criminologen van wie de walgingsgevoeligheid was gemeten aan een onderzoek onderworpen waarbij ze foto's van plaatsen delict moesten bestuderen, casusinformatie moesten lezen, en vervolgens een inschatting moesten geven over de ernst van het delict en de strafmaat. Hun kijkgedrag werd met behulp van eyetracking vastgelegd. De resultaten van dit onderzoek laten zien dat meer walgingsgevoelige deelnemers langer en vaker focussen op het bloed van het slachtoffer, meer negatieve emoties rapporteren in reactie op de foto's, het delict als ernstiger percipiëren en hogere straffen toewijzen dan minder walgingsgevoelige deelnemers. In het licht van de geschetste ontwikkelingen is deze bevinding van belang. Nader onderzoek zal moeten uitwijzen hoe dit werkt bij professionals in de strafrechtsketen.

Zoals gezegd bevat dit nummer een breed scala aan onderzoeken. Soms gaat het om observaties of metingen van wat zich in de praktijk voltrekt. In andere gevallen zijn de experimentele taken benaderingen van processen die in werkelijkheid plaatsvinden. Die benaderingen liggen nu eens dicht bij die werkelijkheid en dan weer vrij ver ervanaf. In alle gevallen roepen criminologische experimenten de vraag op of er grenzen zijn aan wat je experimenteel kunt, mag en moet toetsen. Uiteindelijk is het aan de onderzoekers om daarin te kiezen, uiteraard binnen de grenzen van wat wettelijk en ethisch toelaatbaar is, en om te verantwoorden waarom zij veronderstellen dat gevonden verbanden relevant zijn en ons verder brengen in ons denken. Ook is het de taak van de onderzoekers om die stappen te zetten die nodig zijn om bevindingen te kunnen duiden en om te proberen de beperkingen die gebruikte methoden met zich meebrengen in een volgend onderzoek te ondervangen. De auteurs die een bijdrage leverden aan dit themanummer gaan hier in hun discussieparagrafen uitgebreid op in. Het is aan ons, criminologen, om de suggesties die worden gedaan voor vervolgonderzoek op te pakken, te ondersteunen, te stimuleren of aan te vullen met nieuwe suggesties en benaderingen. Zo kunnen we met de resultaten van deze experimentele exercities de wetenschap en de praktijk verder helpen.

\section{Literatuur}

Bijleveld, C.C.J.H. (2003). Mens, durf te meten! Over methoden en technieken van criminologisch onderzoek. Den Haag: Boom Juridische uitgevers. 
Laan, P.H. van der, Busschbach, J.J. van \& Bijleveld, C.C.J.H. (2007). Experimentele criminologie en criminologische experimenten. Tijdschrift voor Criminologie, 49(1), 3-11.

Pawson, R. \& Tilley, N. (1998). Caring communities, paradigm polemics, design debaters. Evaluation, 4, 73-90. 